\title{
Effects of hydrologic connectivity on aquatic macroinvertebrate assemblages in different marsh types
}

\author{
Sung-Ryong Kang ${ }^{1, *}$, Sammy L. King ${ }^{2}$ \\ ${ }^{1}$ School of Renewable Natural Resources, LSU AgCenter, Baton Rouge, Louisiana 70803-4301, USA \\ ${ }^{2}$ US Geological Survey, Louisiana Fish and Wildlife Cooperative Research Unit, LSU AgCenter, Baton Rouge, \\ Louisiana 70803-4301, USA
}

\begin{abstract}
Hydrologic connectivity can be an important driver of aquatic macroinvertebrate assemblages. Its effects on aquatic macroinvertebrate assemblages in coastal marshes, however, are relatively poorly studied. We evaluated the effects of lateral hydrologic connectivity (permanently connected ponds: PCPs; temporary connected ponds: TCPs), and other environmental variables on aquatic macroinvertebrate assemblages and functional feeding groups (FFGs) in freshwater, brackish, and saline marshes in Louisiana, USA. We hypothesized that (1) aquatic macroinvertebrate assemblages in PCPs would have higher assemblage metric values (density, biomass, Shannon-Wiener diversity) than TCPs and (2) the density and proportional abundance of certain FFGs (i.e. scrapers, shredders, and collectors) would be greater in freshwater marsh than brackish and saline marshes. The data in our study only partially supported our first hypothesis: while freshwater marsh PCPs had higher density and biomass than TCPs, assemblage metric values in saline TCPs were greater than saline PCPs. In freshwater TCPs, long duration of isolation limited access of macroinvertebrates from adjacent water bodies, which may have reduced assemblage metric values. However, the relatively short duration of isolation in saline TCPs provided more stable or similar habitat conditions, facilitating higher assemblage metric values. As predicted by our second hypothesis, freshwater PCPs and TCPs supported a greater density of scrapers, shredders, and collectors than brackish and saline ponds. Aquatic macroinvertebrate assemblages seem to be structured by individual taxa responses to salinity as well as pond habitat attributes.
\end{abstract}

KEY WORDS: Coastal marsh - Aquatic macroinvertebrate assemblage · Hydrologic connectivity · Functional feeding groups

\section{INTRODUCTION}

Hydrologic connectivity refers to the passage of water from one part of the landscape to another (Bracken \& Croke 2007) and the spatiotemporal exchange pathways of water and energy along longitudinal and lateral dimensions (Roach et al. 2009). In floodplain ecosystems, hydrologic connectivity has a profound impact on macroinvertebrate assemblages (Karaus 2004, Paillex et al. 2007, Leigh \& Sheldon
2009, Zilli \& Marchese 2011). The effects of hydrologic connectivity on macroinvertebrate assemblages in coastal marshes, however, are relatively unknown and poorly studied. In these systems, hydrologic connectivity to upstream freshwater sources and downstream saltwater systems create a diversity of habitats that have considerable abiotic variation within and among habitats (Kang 2011), thus potentially influencing macroinvertebrate assemblages (e.g. composition, density, biomass, proportional abundance of 
functional feeding groups). The water depth associated with lateral hydrologic connectivity can impact movement of aquatic organisms (Humphries \& Baldwin 2003).

According to previous studies, abiotic (Poff 1997, Hieber et al. 2005) and biotic (Hornung \& Foote 2006) variables at a local scale are often filters for the regional pool of taxa. When water levels decrease enough to disconnect ponds from other water bodies, aquatic organisms become stranded in the disconnected areas. High lateral connectivity of surface water among individual water bodies may facilitate movement and biotic exchange among them, thus resulting in high similarity of aquatic macroinvertebrate assemblages (Karaus 2004). Boix et al. (2008) also noted that salinity plays a major role in shaping aquatic macroinvertebrate assemblage structure, although their study did not sample across the full salinity gradient (i.e. freshwater to saline marsh). Furthermore, macrophyte cover, here referred to as submerged aquatic vegetation (SAV) cover, appears to affect macroinvertebrate distribution by providing refuge from predators (Mittelbach 1988), increasing the availability of food resources (Campeau et al. 1994), and furnishing attachment sites or building materials (Lodge 1985, Dudley 1988).

Variation across gradients of hydrologic connectivity, salinity, and other environmental factors can also affect the spatial and temporal distribution of macroinvertebrate functional feeding groups (FFGs) that reflects aquatic ecosystem attributes (Rawer-Jost et al. 2000). During recent decades, the categorization of macroinvertebrates into FFGs has shown considerable promise as a tool for assessing spatial changes of communities based on environmental conditions (Wallace \& Webster 1996, Blasius \& Merritt 2002). For instance, Wissinger et al. (2009) noted that predators (e.g. damselflies, dragonflies) are more abundant in wetlands with long hydroperiods (i.e. permanent habitats). Moreover, scrapers, piercers, shredders, and collectors may have a relatively higher density and account for a greater proportion of total macroinvertebrates in freshwater marshes than in brackish and saline marshes because SAV cover is generally higher in freshwater (Diehl \& Kornijow 1998). However, to our knowledge, no studies have evaluated the effects of environmental variables across the full salinity gradient on FFGs in coastal marsh ecosystems.

Water-column macroinvertebrate assemblages in coastal marshes are relatively unknown and poorly studied. Moreover, water-column macroinvertebrates in coastal marshes are important prey items for predatory fish (Batzer et al. 2000) and waterbirds (Bolduc \& Afton 2003). Therefore, macroinvertebrate density and biomass can provide important information about potential foraging habitat values for fish and birds.

A clear understanding of the links among hydrologic connectivity, environmental variables, and aquatic macroinvertebrate assemblages would enhance our understanding of aquatic macroinvertebrate habitat requirements and the current and potential foraging habitat value of marsh ponds for vertebrate predators. The principal objectives of this study were to: (1) examine the effects of lateral hydrologic connectivity (permanently connected ponds [PCPs] and temporary connected ponds [TCPs]) on aquatic macroinvertebrate assemblage metric values (i.e. density, biomass, Shannon-Wiener diversity) and on the distribution of FFGs in a coastal marsh system; and (2) compare patterns of aquatic macroinvertebrate assemblage and FFG composition in different marsh types (i.e. freshwater, brackish, saline). We hypothesized that (1) aquatic macroinvertebrate communities in PCPs would have higher density, biomass, and Shannon-Wiener diversity than in TCPs and (2) the density and proportional abundance of certain FFGs (i.e. scrapers, shredders, and collectors) would be greater in freshwater marsh than in brackish and saline marshes.

\section{METHODS}

\section{Study sites}

This study was conducted in Rockefeller State Wildlife Refuge $\left(29^{\circ} 40^{\prime} \mathrm{N}, 92^{\circ} 48^{\prime} \mathrm{W}\right)$ and White Lake Wetlands Conservation Area $\left(29^{\circ} 52^{\prime} \mathrm{N}, 92^{\circ} 31^{\prime} \mathrm{W}\right)$ in the Chenier Plain, southwestern Louisiana, USA (Fig. 1). The area extended south to north across 3 (freshwater, brackish, saline) vegetation-salinity areas defined and mapped by Chabreck \& Linscombe (1997). Rockefeller State Wildlife Refuge and White Lake Wetlands Conservation Area are not, however, hydrologically connected by a channel due to water control structures between the 2 areas.

We used marsh vegetation to define our marsh types because vegetation reflects the salinity conditions of the recent past, as marsh plants respond to, and integrate local salinity patterns (Visser et al. 1998, Rozas \& Minello 2010). Furthermore, salinity ranges were a major consideration in our decision to select marsh types based on dominant marsh vegetation (i.e. freshwater marsh: Panicum hemitomon; 

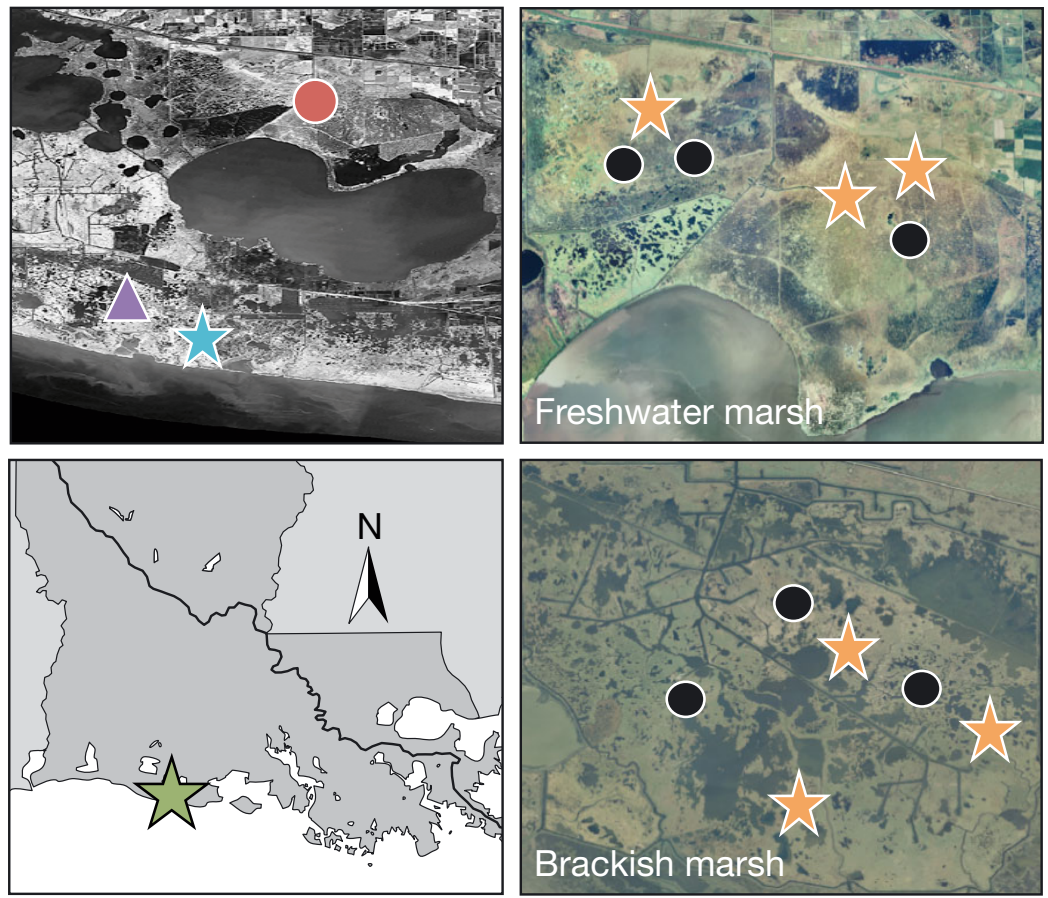

Fig. 1. Freshwater (White Lake Wetlands Conservation Area, red circle), brackish and saline (Rockefeller State Wildlife Refuge, purple triangle and blue star, respectively) marshes located in the Chenier Plain, southwestern Louisiana, USA. Panels on right show location of sampling points in permanently connected ponds (PCPs, black circle)) and temporary connected ponds (TCPs, orange star))

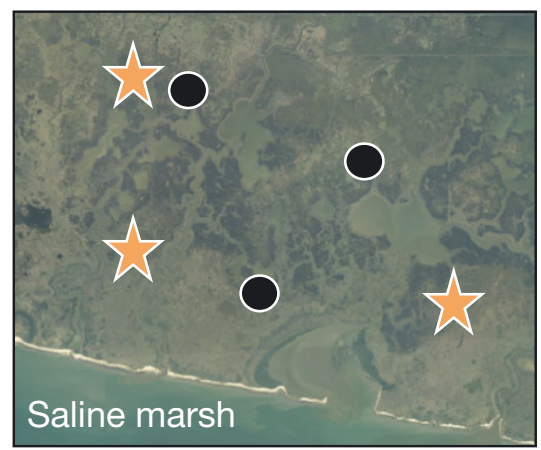

slowed water release from the marsh. Like most coastal marshes in the United States, conditions at our study sites are the product of almost a century of hydrologic modification. All Chenier marshes in Louisiana are affected by oil canals and water control structures (Gunter \& Shell 1958, Morton 1973).

\section{Environmental data collection}

All ponds in the study sites were identified from aerial photography and field visits, and were then classified as either a PCP or a TCP (i.e. PCP: permanently connected channel during all seasons; TCP: transiently connected by surface water to the surrounding marsh but not permanently connected to a channel). TCPs did not have an obvious connecting channel. We randomly selected 3 PCPs and 3 TCPs in each marsh type (total 18 ponds: 3 sampling ponds $\times 2$ pond types $\times 3$ marsh types).

We deployed a water-level recorder in the interior of each pond in November 2008 to measure water depth 6 times per day until the end of the study (May 2010). In addition, a staff gage was established at the border between the pond margin and emer-

brackish marsh: Spartina patens; saline marsh: Spartina alterniflora) rather than immediate salinity conditions at the time samples were collected (Chabreck \& Nyman 2005).

The 42400 ha Rockefeller State Wildlife Refuge consists of 17 impoundments that allow for control of both water level and salinity of the enclosed marsh through flap gates, weirs, and gated culverts (Wicker et al. 1983). The Unit Six management unit (7200 ha, salinity 0.9 to $8.1 \mathrm{ppt}$ ) of Rockefeller State Wildlife Refuge was selected as tidal brackish marsh habitat, and was dominated by Spartina patens and Typha latifolia. An unmanaged area of the refuge (salinity 2.2 to $27.7 \mathrm{ppt}$ ) of similar size and dominated by Spartina alterniflora was selected as tidal saline marsh habitat. White Lake Wetlands Conservation Area is 28719 ha of freshwater marsh (salinity 0.2 to $1.7 \mathrm{ppt}$ ) dominated by Panicum hemitomon and Sagittaria lancifolia. The freshwater marsh had water control structures that gent marsh. Measurements taken with the waterlevel recorder and the staff gage were used to calculate 2 hydrologic metric values: connected water depth (CWD) and duration of isolation (DI). CWD was the water depth at the pond-marsh border measured when the pond was connected by surface water to a channel or surrounding marsh (marginal zone of the pond). PCPs typically had a gradually sloped bank whereas TCPs had a more vertical bank. These edge shapes may affect CWD. DI is a measure of the duration of disconnection, in days per month, among the pond, channel, and emergent marsh. This is the number of days that water was $0 \mathrm{~cm}$ deep at the marsh edge.

The aquatic environment of ponds was characterized monthly when we collected macroinvertebrate samples. We measured temperature, salinity, and dissolved oxygen (DO) with the YSI Model 85 Water Quality Monitor. Percent SAV cover in a $1 \times 1 \mathrm{~m}$ 
frame was also determined at 3 points in sampling ponds and the mean cover was determined. We used a meter stick to check sampling point water depth (SPWD) i.e. the water depth at sampling points.

\section{Aquatic macroinvertebrate sampling and identification}

We defined aquatic macroinvertebrates by body size (i.e. $>1 \mathrm{~mm}$ body length and width) and only considered aquatic insects, amphipods, and isopods in our collections. To determine aquatic macroinvertebrate assemblage structure, we sampled each pond monthly from April 2009 to May 2010 (3 sampling sites $\times 2$ pond types $\times 3$ marsh types $\times 14$ months $=$ 252 samples). We sampled water-column macroinvertebrates using a D-shaped sweep net with a $30 \mathrm{~cm}$ opening and $1 \mathrm{~mm}$ mesh size. Many previous studies (Bolduc \& Afton 2003, Batzer et al. 2004, Nicolet et al. 2004, Tarr et al. 2005, Hornung \& Foote 2006, Kratzer \& Batzer 2007) have found a D-shaped sweep net is an effective sampling method for macroinvertebrate sampling in ponds. We conducted a total of 10 continuous sweeps, each of $2 \mathrm{~m}$ long (surface covered $6 \mathrm{~m}^{2}$; Bolduc \& Afton 2003) at a randomly selected point near the edge of each pond. All collected individuals were stored in $80 \%$ ethanol and later identified and counted. Following identification, aquatic macroinvertebrates were stored for $1 \mathrm{wk}$ in distilled water to allow for recovery of body condition (Gammonley \& Laubhan 2002). Wet weight (g) was measured by draining the distilled water from each sample and allowing animals to air dry for 5 min before weighing on a microbalance (Newcomb et al. 2001). To determine biomass, each combined monthly sample (i.e. all macroinvertebrates together) from each pond was weighed to the nearest $0.001 \mathrm{~g}$ wet weight.

We identified macroinvertebrates to genus level except the Diptera group, which was identified to the family level. Recently, several published papers from many different ecosystems have examined the practicality and accuracy of using various taxonomic levels of invertebrates for assemblage analyses (Dauvin et al. 2003; Anderson et al. 2005). It was found that family-level identifications were adequate to infer patterns in assemblage structure for invertebrates and that aggregating data at the family and species levels were highly correlated (Olsgard et al. 2003, Hirst 2006). In addition, Konar \& Iken (2009) noted that species-level may yield more error than genus in identifications, which may bias the interpretation of the results. Therefore, we believe that genera resolu- tion is adequate to infer aquatic macroinvertebrate assemblage patterns in our coastal marsh system.

\section{FFGs}

Changes in habitat condition can be reflected by the proportional differences in FFGs that are associated with particular food and habitat types (Merritt \& Cummins 2008). We focused on variation in the relative proportions of the FFGs across different salinity gradients.

\section{Statistical analyses}

ANOVA and $t$-tests (Proc Mixed, Version 9.2, SAS Institute) were used to test for statistical differences in environmental variables, aquatic macroinvertebrate density, biomass, and Shannon-Wiener diversity within a pond type across marshes (e.g. comparison of values for PCPs among freshwater, brackish, saline marsh) and between pond types within a marsh (e.g. values for PCPs vs. TCPs in freshwater marshes). We used 1-way ANOVA for each response variable. Models included the environmental variable, as well as density, biomass, and ShannonWiener diversity. We conducted a 1-way ANOVA with 1 fixed effect. Significant ANOVA effects were tested using post-hoc comparisons of Tukey adjusted least squared means. For ANOVA analyses, data were tested for normality with the Shapiro-Wilks test. In the event that the residuals were not normally distributed, the data were log transformed. Data are reported as mean $\pm \mathrm{SE}$, and significance level was set at $\alpha=0.05$.

Canonical correspondence analysis (CCA), using CANOCO 4.5 (ter Braak \& Smilauer 2002), was carried out to investigate potential associations between log-transformed density and environmental variables at all sites. A taxon was included in the CCA if more than 3 individuals were collected in the samples (Gauch 1982, Piazza \& La Peyre 2011).

\section{RESULTS}

\section{Environmental variables}

The mean $( \pm \mathrm{SE})$ diameter of randomly selected PCPs and TCPs was $99.0 \pm 14.6 \mathrm{~m}$ and $75.4 \pm 17.7 \mathrm{~m}$, respectively. Saline PCPs and TCPs had greater salinity than brackish and freshwater PCPs and TCPs 
Table 1. Comparison of of environmental variables by pond type among freshwater, brackish and saline marshes in southwestern Louisiana from April 2009 to May 2010. PCP: permanently connected pond; TCP: temporary connected pond; DO: dissolved oxygen; SPWD: sampling point water depth; CWD: connected water depth; DI: duration of isolation; SAV: submerged aquatic vegetation. $\mathrm{n}=42$ (3 sampling ponds in each pond type $\times 14 \mathrm{mo}$ ) for all variables, except CWD and DI $(\mathrm{n}=1278$, 3 sampling ponds $\times 426 \mathrm{~d})$ and SAV cover: $(\mathrm{n}=15,3$ sampling ponds $\times 5$ seasons). Values are means $( \pm \mathrm{SE})$

\begin{tabular}{|c|c|c|c|c|c|c|}
\hline & \multicolumn{2}{|c|}{- Freshwater } & \multicolumn{2}{|c|}{ Brackish } & \multirow{2}{*}{\multicolumn{2}{|c|}{$\frac{}{\mathrm{PCP}}$ Saline $\frac{}{\mathrm{TCP}}$}} \\
\hline & PCP & TCP & PCP & $\mathrm{TCP}$ & & \\
\hline Salinity (ppt) & $0.9(0.24)$ & $0.3(0.06)$ & $4.1(1.21)$ & $4.0(1.06)$ & $13.1(2.14)$ & $12.3(2.51)$ \\
\hline $\mathrm{DO}\left(\mathrm{mg} \mathrm{l}^{-1}\right)$ & $2.8(0.73)$ & $2.5(0.66)$ & $4.4(0.60)$ & $4.6(0.43)$ & $4.5(0.58)$ & $4.0(0.53)$ \\
\hline Temperature $\left({ }^{\circ} \mathrm{C}\right)$ & $24.3(3.46)$ & $23.4(3.23)$ & $23.2(3.17)$ & 23.7 (3.33) & $24.8(2.94)$ & $25.3(3.35)$ \\
\hline SPWD (cm) & $31.7(2.79)$ & $31.8(5.41)$ & $31.3(5.90)$ & $34.6(6.28)$ & $15.1(2.64)$ & $22.1(2.50)$ \\
\hline CWD $(\mathrm{cm})$ & $19.4(6.40)$ & $18.2(5.43)$ & $28.1(7.42)$ & $31.2(7.48)$ & $13.8(3.12)$ & $20.9(3.44)$ \\
\hline $\mathrm{DI}\left(\mathrm{d} \mathrm{mo}^{-1}\right)$ & $0.0(0.00)$ & $8.5(4.75)$ & $0.0(0.00)$ & $3.8(2.73)$ & $0.0(0.00)$ & $1.3(0.95)$ \\
\hline SAV cover $(\%)$ & 34.5 (4.39) & $32.0(5.52)$ & $14.2(4.77)$ & $12.1(4.07)$ & $0.0(0.00)$ & $0.0(0.00)$ \\
\hline
\end{tabular}

(PCPs: $F_{2,123}=26.97, \mathrm{p}<0.01 ;$ TCPs: $F_{2,123}=34.54, \mathrm{p}<$ $0.01)$. DO was higher in brackish $\left(4.6 \pm 0.43 \mathrm{mg} \mathrm{l}^{-1}\right)$ than in freshwater $\left(2.5 \pm 0.66 \mathrm{mg} \mathrm{l}^{-1}\right) \mathrm{TCPs}\left(F_{2,123}=\right.$ $4.49, \mathrm{p}=0.04$ ) but did not differ in PCPs. Freshwater PCPs and TCPs had greater SAV cover than brackish and saline PCPs and TCPs (PCPs: $F_{2,42}=9.88, \mathrm{p}=0.01$; TCPs: $F_{2,42}=8.43, \mathrm{p}=0.02$ ) (Table 1). SPWD was higher in freshwater $(31.7 \pm 2.79 \mathrm{~cm})$ and brackish $(31.3 \pm 5.90 \mathrm{~cm})$ than in saline $(15.1 \pm 2.64 \mathrm{~cm})$ PCPs $\left(F_{2,123}=5.44, \mathrm{p}=0.02\right)$ but did not differ in TCPs. Temperature, CWD, and DI did not differ within a pond type across marshes.
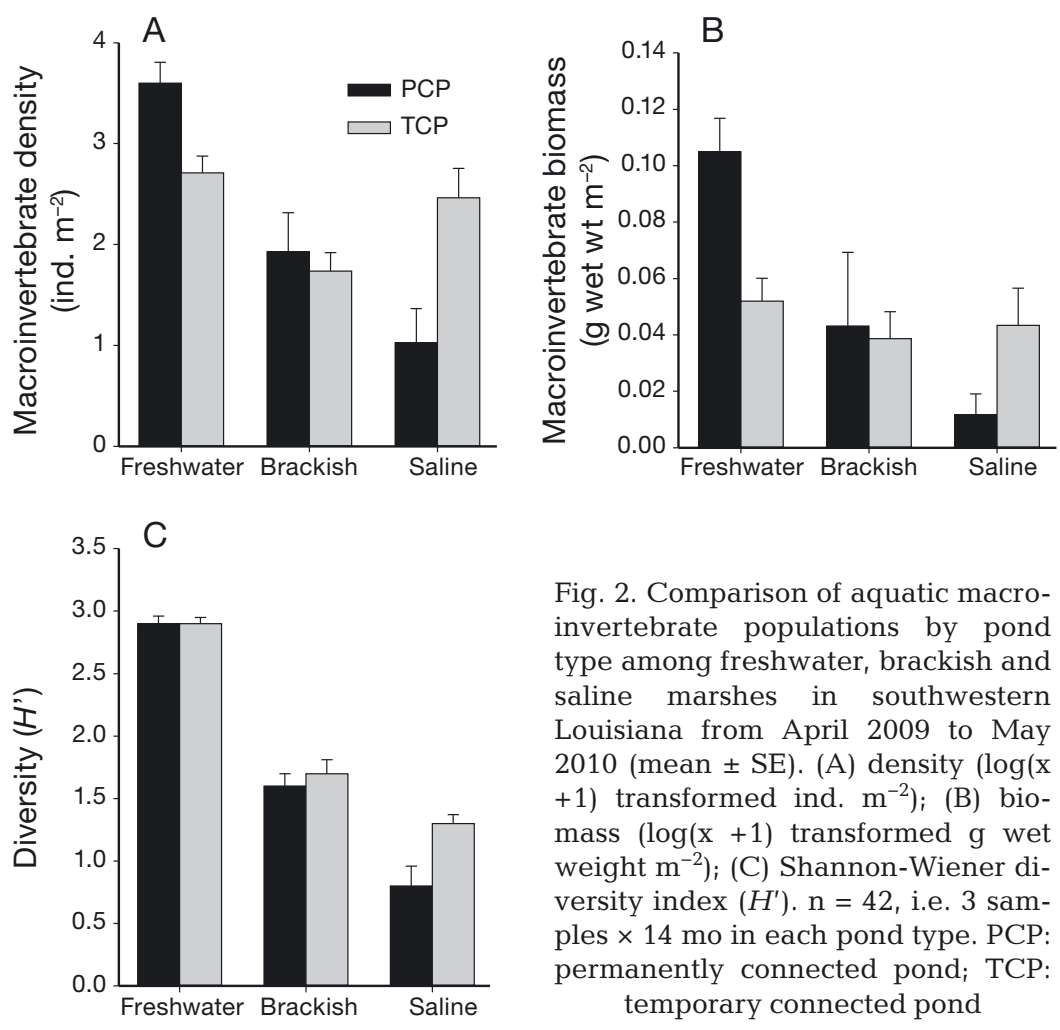

Fig. 2. Comparison of aquatic macroinvertebrate populations by pond type among freshwater, brackish and saline marshes in southwestern Louisiana from April 2009 to May 2010 (mean $\pm \mathrm{SE}$ ). (A) density $(\log (\mathrm{x}$ +1) transformed ind $\mathrm{m}^{-2}$ ); (B) biomass $(\log (\mathrm{x}+1)$ transformed $\mathrm{g}$ wet weight $\mathrm{m}^{-2}$ ); (C) Shannon-Wiener diversity index $\left(H^{\prime}\right) . \mathrm{n}=42$, i.e. 3 samples $\times 14$ mo in each pond type. PCP: permanently connected pond; TCP: temporary connected pond
Between pond types within a marsh, all environmental variables did not differ.

\section{Aquatic macroinvertebrate density and biomass}

Aquatic macroinvertebrate density within a pond types within a marsh, density was higher in freshwain TCPs $(t=3.34, \mathrm{p}<0.01)$; however, density was higher in saline TCPs than in PCPs $(t=3.71, \mathrm{p}=0.01)$. No differences were observed between brackish PCPs and TCPs. Chironomidae and Trichocorixa were abundant taxa (>1.0 ind. $\mathrm{m}^{-2}$ ) across all marshes (Table 2). Density of Chironomidae was greatest in the freshwater marsh, and Trichocorixa density was higher in brackish and saline marshes than in the freshwater marsh.

The patterns for biomass were similar to those found for density. Aquatic macroinvertebrate biomass within a pond type across marshes indicated freshwater PCPs supported higher biomass than brackish and saline PCPs $\left(F_{2,123}=20.72, \mathrm{p}<0.01\right)$ but biomass in TCPs did not differ $\left(F_{2,123}=0.86, \mathrm{p}=0.43\right)$ (Fig. 2B). Between pond types within a marsh, biomass in freshwater PCPs was greater than in freshwater TCPs $(t=$ $3.62, \mathrm{p}<0.01$ ), and greater in saline 


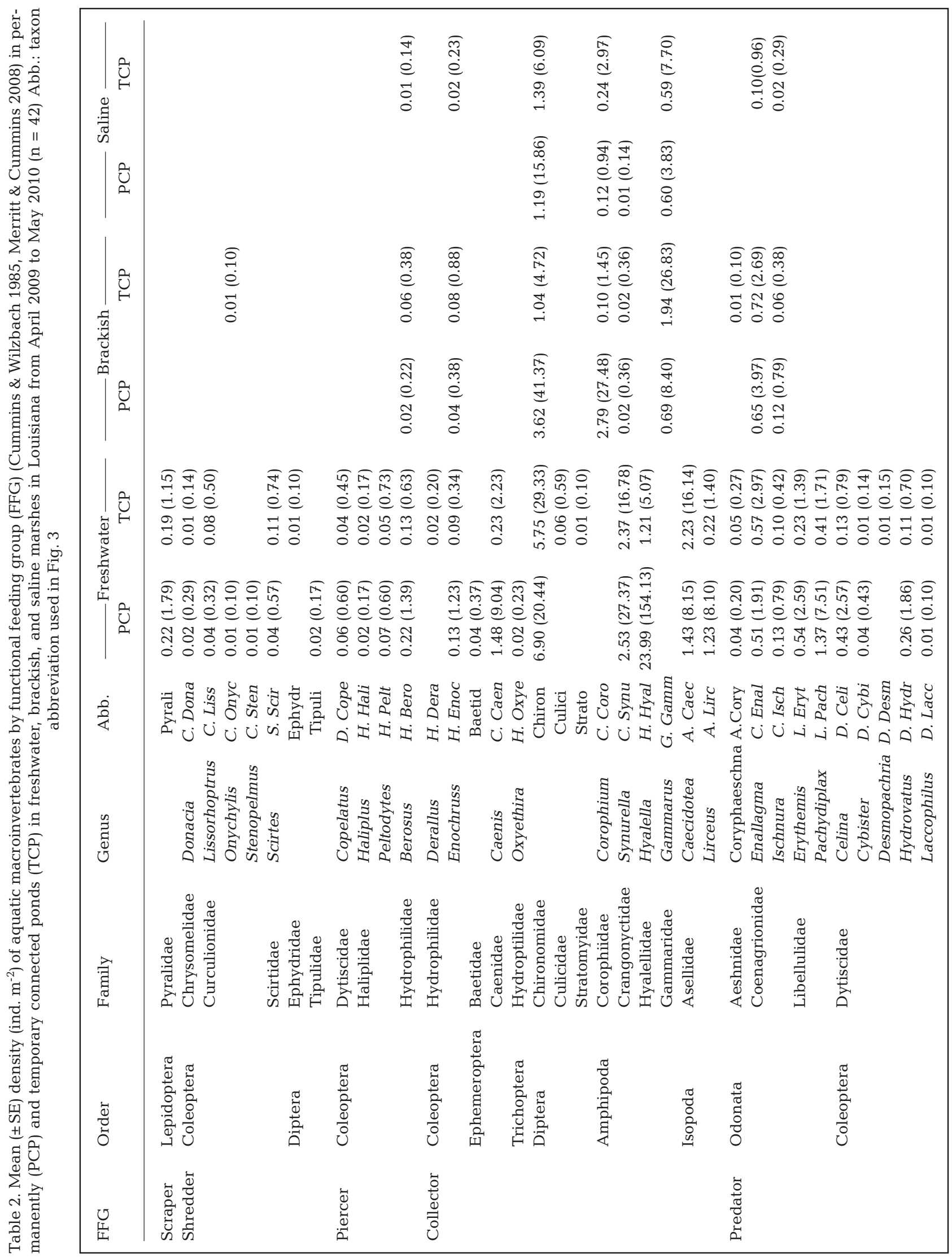




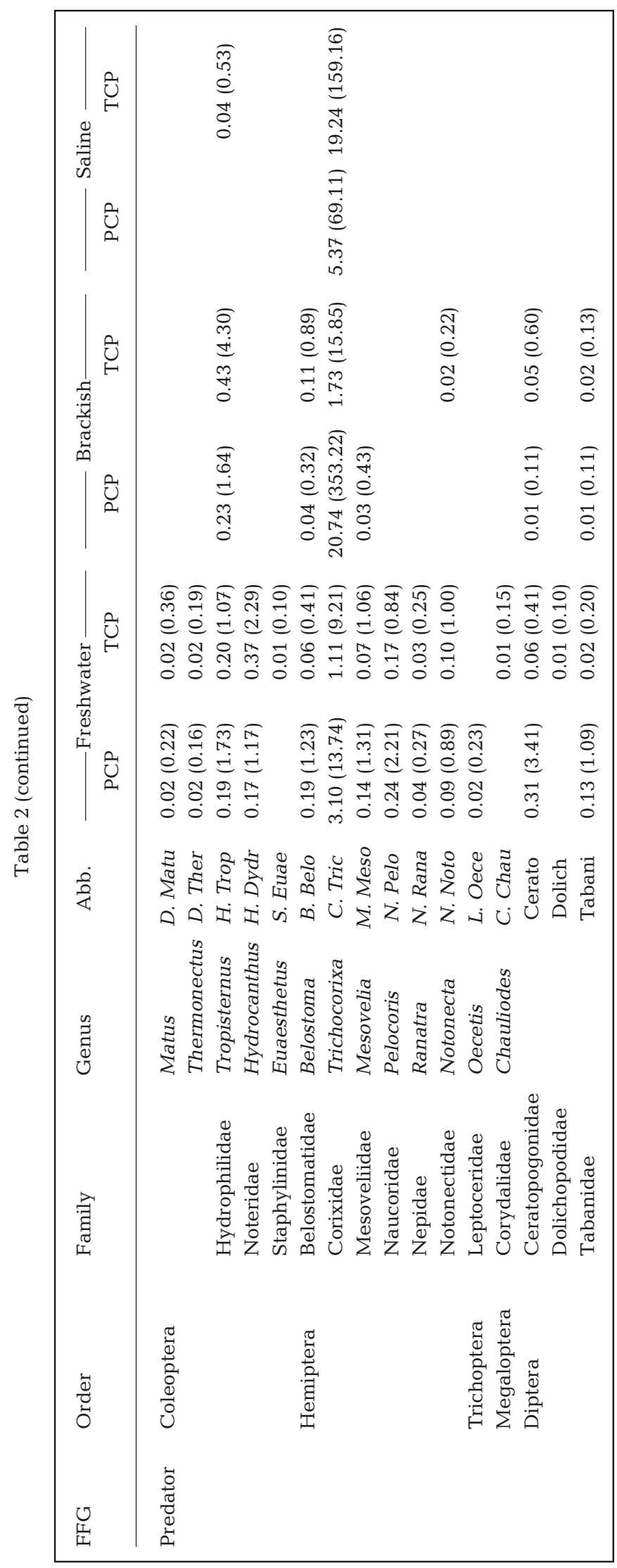

TCPs than in saline PCPs $(t=3.06, \mathrm{p}<0.01)$. Brackish PCPs and TCPs did not differ.

\section{Aquatic macroinvertebrate diversity}

The 52 aquatic macroinvertebrate taxa included 47 taxa (20 855 ind.) in PCPs and 49 taxa (11 275 ind.) in TCPs. A total of 50 taxa were collected from freshwater marsh (PCPs: 45 taxa, 11708 ind.; TCPs: 46 taxa, 4205 ind.), 20 in brackish marsh (PCPs: 15 taxa, 7311 ind.; TCPs: 18 taxa, 1609 ind.), and 12 in saline marsh (PCPs: 7 taxa, 1836 ind.; TCPs: 12 taxa, 5461 ind.). Freshwater marsh had 32 exclusive taxa, brackish and saline marshes had no exclusive taxa (Table 2).

Shannon-Wiener diversity within a pond type across marshes indicated that diversity was highest in freshwater PCPs and TCPs and lowest in saline PCPs and TCPs (PCPs: $F_{2,123}=84.81, \mathrm{p}<0.01$; TCPs: $F_{2,123}=97.86, \mathrm{p}<0.01$ ) (Fig. 2C). Between pond types within a marsh, PCPs and TCPs did not differ in freshwater and brackish marsh, but TCPs in the saline marsh had greater diversity than PCPs $(t=$ $3.08, \mathrm{p}<0.01)$.

\section{Aquatic macroinvertebrate assemblage composition}

The CCA results (Fig. 3) indicated significant relationships between the measured environmental variables and aquatic macroinvertebrate assemblage structure during all sampling periods (Axis 1: p < 0.01 , all axes: $p<0.01$ ). The first 2 axes of the taxaenvironment relationship represented $78.5 \%$ of the variance. Axis 1 was correlated positively to salinity $(0.75)$ and Axis 2 related most strongly with water depth (SPWD: 0.60; CWD: 0.64).

Visual inspection of the taxa-environment relationships based on relative distance from the origin and orientation of taxa and variable vectors indicated that relatively abundant $\left(>0.5\right.$ ind. $\left.\mathrm{m}^{-2}\right)$ or exclusive taxa in brackish and saline (e.g. Gammarus, Corophium, Trichocorixa, Chironomidae) marshes were associated positively with salinity and DO. Also, relatively abundant taxa in freshwater marsh (e.g. Odonata: Pachydiplax; Amphipoda: Synurella; Isopoda: Lirceus) were associated positively with SAV cover and water depth. Relatively low density taxa $\left(<0.1\right.$ ind. $\left.\mathrm{m}^{-2}\right)$ in freshwater ponds such as Coleoptera (Copelatus, Cybister; Desmopachria) were positively associated with DI and temperature (Fig. 3). 


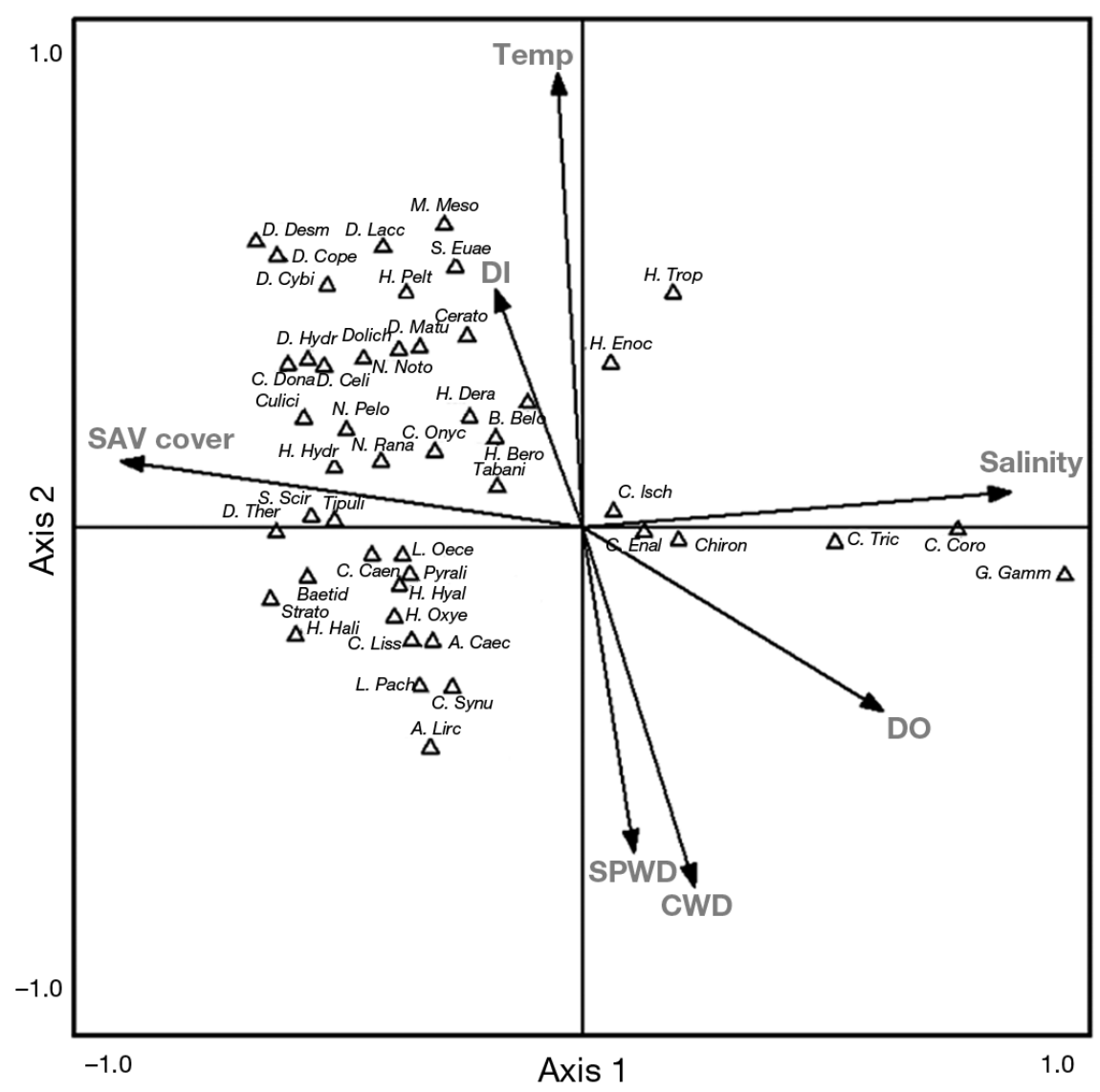

Fig. 3. Association of environmental variables and aquatic macroinvertebrate assemblage structure based on canonical correspondence analysis (CCA), for all ponds and marshes studied in southwestern Louisiana from April 2009 to May 2010. Full names and abbreviations of taxa are listed in Table 2. DO: dissolved oxygen; Temp: temperature; SPWD: sampling point water depth; CWD: connected water depth; DI: duration of isolation; SAV: submerged aquatic vegetation

within saline marsh, PCPs supported lower predator density than TCPs $(t=4.44, \mathrm{p}<0.01)$ based on 1 taxon, Trichocorixa.

\section{DISCUSSION}

\section{Aquatic macroinvertebrate assemblages}

The structure of macroinvertebrate assemblages clearly differed with pond salinity in our study, but other variables that co-vary with salinity (e.g. SAV cover) also appeared to be important in structuring these assemblages, and agrees with other studies (Williams \& Williams 1998, Cognetti \& Maltagliati 2000, Smith 2001, Velasco et al. 2006, Boix et al. 2008). Relatively low-salinity PCPs and TCPs in the freshwater marsh showed the highest mean density, biomass, and Shannon-Wiener diversity while relatively high-salinity PCPs and TCPs in saline marsh had the lowest values and indices. One of the most important habitat attributes that co-varied with salinity was SAV cover, which was inversely related to the salinity gradient. Taxa number also clearly declined

\section{FFGs}

Within a pond type across marshes, the density and proportional abundance of all FFGs except predators were greater in freshwater ponds than brackish and saline ponds (scrapers: $F_{2,249}=21.78, \mathrm{p}$ $<0.01$; shredders: $F_{2,249}=37.57, \mathrm{p}<0.01$; piercers: $F_{2,249}=49.52, \mathrm{p}<0.01$; collectors: $F_{2,249}=20.37, \mathrm{p}<$ $0.01 ; F_{2,249}=1.39, \mathrm{p}=0.26$ ) (Table 2). Predator density in TCPs was higher in brackish and saline marsh than freshwater marsh (predators: $F_{2,123}=$ 6.38, $\mathrm{p}<0.01$ ) due almost strictly to Trichocorixa. Within brackish marsh, piercers were more abundant in TCPs than PCPs $(t=2.13, \mathrm{p}=0.04)$ based on 1 taxon, Berosus, and within freshwater marsh, collector density was greater in PCPs than TCPs $(t=$ 3.10, p < 0.01) based on 1 taxon, Hyalella. Moreover, within freshwater marsh, predator density was higher in PCPs than in TCPs $(t=2.65, \mathrm{p}=0.01)$, but from freshwater to saline ponds. However, responses to salinity varied among taxa and FFGs.

In addition, our results are at least partially a result of hydrologic connectivity across multiple scales. At the broader scale, the distribution of fresh, brackish, and saline marshes are a result of their respective connectivity to rivers and the Gulf coast. At a more local scale, the temporary or permanent connection to adjacent water bodies also influences environmental characteristics. In particular, all of our brackish ponds were subjected to structural marsh management, which involves placing levees and watercontrol structures in a marsh to facilitate water-level and/or salinity management (Wicker et al. 1983). Structural marsh management may restrict direct access of predatory fish or crustaceans by reducing or blocking water exchange (Morton 1973, Rozas \& Minello 1999) and thus may reduce predation on macroinvertebrate prey-and thereby influence 
macroinvertebrate structure-in managed ponds. However, we are unaware of studies that have evaluated macroinvertebrate assemblages in unmanaged or managed brackish marshes, thus the effects of management are unknown.

Variation in CWD and DI, both measures of hydrologic connectivity, across marsh types was also important. Similar findings have been reported for water bodies in floodplain systems; for example Leigh \& Sheldon (2009) considered hydrological connectivity a key driver of aquatic macroinvertebrate structural composition in these habitats. The duration of connection between ponds affects the density, species richness, and Shannon-Wiener diversity of aquatic invertebrate assemblages in floodplain systems as well (Ward 1998, Tockner et al. 1999, Amoros \& Bornette 2002, Ward et al. 2002, Karaus 2004, Whiles \& Goldowitz 2005). However, the data in our study only partially agree with these other studies. In our study, the effects of connectivity were inconsistent in that freshwater marsh PCPs had higher density and biomass than TCPs, whereas assemblage metric values in saline TCPs were greater than saline PCPs. In freshwater TCPs, the relatively long DI $(8.5 \pm 4.75 \mathrm{~d}$ $\mathrm{mo}^{-1}$ ), which would limit access to these ponds by macroinvertebrates from adjacent water bodies, may have reduced assemblage metric values; whereas the relatively short DI $\left(1.3 \pm 0.95 \mathrm{~d} \mathrm{mo}^{-1}\right)$ in saline TCPs may have provided more stable or similar habitat conditions facilitating higher assemblage metric values.

\section{Distribution of FFGs}

The density of scrapers, shredders, piercers, and collectors (i.e. herbivorous groups) in our study decreased with increased salinity but predator density increased. Restriction of herbivorous groups to the freshwater marsh seems to be partially a result of the salinity tolerance of individual taxa. Horrigan et al. $(2005,2007)$ found that the maximum salinity tolerance of taxa and FFGs, such as scrapers (e.g. Pyralidae), shredders (Scirtidae), piercers (Hydrophilidae) and collectors (Culicidae), was about 12 ppt. However, overall density of predators had a positive relationship with increased salinity, which was opposite to the distribution pattern of SAV cover. The reason for the density pattern is probably due to the noticeably increased density of one particular taxon (i.e. Corixidae Trichocorixa) in more saline habitats. Total abundance of Trichocorixa in freshwater marsh (1069 ind.) was lower than in brackish (5661 ind.) and saline (6201 ind.) marshes. Trichocorixa in brackish and saline marshes is known to have a high salinity tolerance (Gunter \& Christmas 1959, Tones \& Hammer 1975, Kelts 1979, Stonedahl \& Lattin 1986, Meutter et. al. 2010), but is apparently a poor competitor in freshwater environments.

The distribution of SAV cover relative to salinity may have an effect on the FFG distribution pattern (Heino 2000, Hornung \& Foote 2006). As predicted by our second hypothesis, freshwater PCPs and TCPs supported a greater density of scrapers, shredders, and collectors than brackish and saline ponds. Freshwater ponds had greater SAV cover than brackish and saline marsh ponds, thus providing better habitat quality and supporting much greater herbivorous group densities than brackish and saline marsh ponds. Similarly, Diehl \& Kornijow (1998) noted that aquatic macroinvertebrates use macrophytes as a refuge from vertebrate predators, a grazing substrate, and a food source. The SAV distribution patterns may have also affected the distribution of some predators. Several abundant predators (Odonata: Aeshnidae, Libellulidae) in freshwater marsh were not observed in saline ponds although they have a relatively high salinity tolerance (i.e. between 5 and 14 ppt, Horrigan et al. 2005). These findings suggest that SAV cover is an important habitat component for herbivorous groups but also that no single environmental trait is responsible for macroinvertebrate distribution patterns across marsh types.

\section{Individual taxa response}

Clearly, FFG distribution patterns are a function of individual taxon responses to the environmental gradients (e.g. SAV cover, salinity). The variation in environmental variables across marsh types creates potentially stressful abiotic and biotic conditions that are unique to each marsh type. In freshwater habitats, low DO produces stressful conditions for many taxa (Jacobsen 2008). Dramatically fluctuating salinities in brackish marshes (Elliott \& Whitfield 2011) and high salinity in saline marshes provide the dominant stressors in these habitats. Thus, we can surmise that the dominant taxa in our study ponds were able to adequately endure or thrive in these stressful habitats, but due to the specificity of the necessary adaptations to thrive in each habitat, no taxon dominated across all marsh and pond types.

Variation in life history traits of macroinvertebrates appears to be correlated with hydrologic condition (i.e. flooding duration, water depth); thus dominant taxa vary with different hydrologic environments. 
Gascon et al. (2007) also noted that in saline marsh, the dominant taxon of benthic organisms differ between permanent (the amphipod Corophium orientale) and temporary (Chironomus gr.) waters. In our study, one of the low-density taxa in freshwater marsh (i.e. Coleoptera: Cybister, Donacia) was negatively associated with water depth, but one of the abundant taxa (i.e. Odonata: Pachydiplax) was positively related with water depth. Coleoptera are known to possess physiological and behavioral mechanisms to survive desiccation during dry periods (e.g. Dytiscidae, Nilsson 1986), and these traits may allow them to avoid deep-water habitat where large and strong predators (e.g. fish, dragonfly) occur. Odonata may require a relatively long hydroperiod for the full development of nymphs even though they appear in shallow water (Wissinger 1988, Zimmer et al. 2001).

Individual taxa also responded to salinity. For instance, 2 taxa, water boatman Trichocorixa and non-biting midge Chironomidae, were found in all marsh types and possess broad salinity tolerances (Trichocorixa: up to $60 \mathrm{ppt}$, Stonedahl \& Lattin 1986; Chironomidae: over 35 ppt, Velasco et al. 2006), but demonstrated opposite density patterns along the salinity gradients. Trichocorixa increased with increasing salinity and Chironomidae decreased with increasing salinity. The fact that Chironomidae (i.e. collector-gatherers) had highest density in freshwater marsh is not surprising because ponds in freshwater marsh provided greater food resources (i.e. SAV cover, Hornung \& Foote 2006) than brackish (less SAV cover) and saline (no SAV cover) marsh ponds during the entire sampling period. Furthermore, the higher density of Trichocorixa in brackish and saline ponds may be because it is a relatively small predator and may compete poorly with large and strong macroinvertebrate predators (e.g. Erythemis and, Pachydiplax, which were the dominant predator taxa in freshwater marsh but were not found in brackish and saline marshes).

\section{CONCLUSIONS}

The goal of our study was to determine the effects of hydrologic connectivity on aquatic macroinvertebrate assemblages by comparing aquatic macroinvertebrate density, biomass, and Shannon-Wiener diversity in ponds of a coastal marsh ecosystem. Our data only partially support our first hypothesis, since while freshwater PCPs had greater density and biomass than freshwater TCPs, assemblage metric val- ues in saline TCPs were greater than in saline PCPs. As predicted by our second hypothesis, with the exception of predators, freshwater PCPs and TCPs supported a greater density and proportional abundance of all FFGs than ponds of brackish and saline marshes. Aquatic macroinvertebrate assemblages seem to be structured by individual taxa responses to salinity as well as pond habitat attributes (SAV cover, hydrologic connectivity). Anthropogenic activities such as mosquito control ditches (Balling et al. 1980) that convert TCPs to PCPs, or structural marsh management that reduces or blocks water exchange, can potentially alter aquatic macroinvertebrate habitat conditions and assemblage structure, and therefore may modify foraging habitat values for aquatic vertebrates.

Acknowledgements. This project was supported by a Louisiana Department of Wildlife and Fisheries and US Fish and Wildlife Service State Wildlife Grant with support also from the International Crane Foundation. We thank M. La Peyre, J. A. Nyman, R. Keim, and A. Rutherford for their critical insights. The authors acknowledge the field and laboratory contributions of J. Linscombe, R. Cormier, M. Huber, and A. Williamson. In addition, we extend gratitude to $\mathrm{M}$. Kaller for statistical and technical assistance. We appreciate the comments of 5 anonymous reviewers, whose suggestions improved this manuscript. Collections were made under Louisiana State University AgCenter Animal Care and Use protocol (\#AE2008-012). Any use of trade, firm, or product names is for descriptive purposes only and does not imply endorsement by the US Government.

\section{LITERATURE CITED}

Amoros C, Bornette G (2002) Connectivity and biocomplexity in waterbodies of riverine floodplains. Freshw Biol 47: 761-776

Anderson MJ, Connell SD, Gillanders BM, Diebel CE, Blom WM, Saunders JE, Landers TJ (2005) Relationships between taxonomic resolution and spatial scales of multivariate variation. J Anim Ecol 74:636-646

Balling SS, Stoehr T, Resh VH (1980) The effects of mosquito control recirculation ditches on the fish community of a San Francisco Bay salt marsh. Calif Fish Game 66:25-34

> Batzer DP, Pusateri CR, Vetter R (2000) Impacts of fish predation on marsh invertebrates: direct and indirect effects. Wetlands 20:307-312

> Batzer DP, Palik BJ, Buech R (2004) Relationships between environmental characteristics and macroinvertebrate communities in seasonal woodland ponds of Minnesota. J N Am Benthol Soc 23:50-68

Blasius BJ, Merritt RW (2002) Field and laboratory investigations on the effects of road salt $(\mathrm{NaCl})$ on stream macroinvertebrate communities. Environ Pollut 120:219-231

Boix D, Gasco S, Sala J, Badosa A and others (2008) Patterns of composition and species richness of crustaceans and aquatic insects along environmental gradients in Mediterranean water bodies. Hydrobiologia 597:53-69 
Bolduc F, Afton AD (2003) Effects of structural marsh management and salinity on invertebrate prey of waterbirds in marsh ponds during winter on the Gulf Coast Chenier Plain. Wetlands 23:897-910

$>$ Bracken LJ, Croke J (2007) The concept of hydrological connectivity and its contribution to understanding runoffdominated geomorphic systems. Hydrol Processes 21: 1749-1763

Campeau S, Murkin HR, Titman RD (1994) Relative importance of algae and emergent plant litter to freshwater marsh invertebrates. Can J Fish Aquat Sci 51:681-692

Chabreck RH, Linscombe J (1997) Vegetation type map of the Louisiana coastal marshes. Louisiana Dept Wildlife Fish, New Orleans, LA

Chabreck RH, Nyman JA (2005) Management of coastal wetlands. In Braun CE (ed) Techniques for wildlife investigations and management, 6th edn. The Wildlife Society, Bethesda, MD, p 839-860

Cognetti G, Maltagliati F (2000) Biodiversity and adaptative mechanisms in brackish water fauna. Mar Pollut Bull 40: $7-14$

Cummins KW, Wilzbach MA (1985) Field procedures for analysis of functional feeding groups of stream macroinvertebrates. Contribution 1611, Appalachian Environmental Laboratory, University of Maryland, Frostburg, $\mathrm{MD}$

> Dauvin JC, Gesteira JLG, Fraga MS (2003) Taxonomic sufficiency: an overview of its use in the monitoring of sublittoral benthic communities after oil spill. Mar Pollut Bull 46:552-555

Diehl S, Kornijow R (1998) Influence of submerged macrophytes on trophic interactions among fish and macroinvertebrates. In Jeppesen E, Sondergaard M, Sondergaard M, Christofferson K (eds) The structuring role of submerged macrophytes in lakes. Springer, New York, NY, p 24-46

Dudley TL (1988) The role of plant complexity and epiphyton in colonization of macrophytes by stream insects. Verh Int Verein Theor Angew Limnol 23:1153-1158

> Elliott M, Whitfield AK (2011) Challenging paradigms in estuarine ecology and management. Estuar Coast Shelf Sci 94:306-314

Gammonley JH, Laubhan MK (2002) Patterns of food abundance for breeding waterbirds in the San Luis Valley of Colorado. Wetlands 22:499-508

- Gascon S, Brucet S, Sala J, Boix D, Quintana XD (2007) Comparison of the effects of hydrological disturbance events on benthos and plankton salt marsh communities. Estuar Coast Shelf Sci 74:419-428

Gauch HG Jr (1982) Multivariate analysis in community ecology. Cambridge University Press, Cambridge

> Gunter G, Christmas JY (1959) Corixid insects as part of the offshore fauna of the sea. Ecology 40:724-725

Gunter G, Shell WE (1958) A study of an estuarine area with water-level control in the Louisiana marsh. Proc Louisiana Acad Sci 21:5-34

- Heino J (2000) Lentic macroinvertebrate assemblage structure along gradients in spatial heterogeneity, habitat size and water chemistry. Hydrobiologia 418:229-242

> Hieber M, Robinson CT, Uehlinger U, Ward JV (2005) A comparison of macroinvertebrate assemblages among different types of alpine streams. Freshw Biol 50: 2087-2100

> Hirst AJ (2006) Influence of taxonomic resolution on multivariate analyses of arthropod and macroalgal reef assemblages. Mar Ecol Prog Ser 324:83-93

Hornung JP, Foote AL (2006) Aquatic invertebrate responses to fish presence and vegetation complexity in western boreal wetlands, with implications for waterbird productivity. Wetlands 26:1-12

Horrigan N, Choy S, Marshall J, Recknagel F (2005) Response of stream macroinvertebrates to changes in salinity and the development of a salinity index. Mar Freshw Res 56:825-833

Horrigan N, Dunlop JE, Kefford BJ, Zavahir F (2007) Acute toxicity largely reflects the salinity sensitivity of stream macroinvertebrates derived using field distributions. Mar Freshw Res 58:178-186

> Humphries P, Baldwin DS (2003) Drought and aquatic ecosystem: an introduction. Freshw Biol 48:1141-1146

Jacobsen D (2008) Low oxygen pressure as a driving factor for the altitudinal decline in taxon richness of stream macroinvertebrates. Oecologia 154:795-807

Kang SR (2011) Aquatic macroinvertebrate and nekton community structure in a Chenier marsh ecosystem: implications for whooping wrane prey availability. PhD dissertation, Louisiana State University, Baton Rouge, LA

Karaus U (2004) The ecology of lateral aquatic habitats along river corridors. PhD dissertation, University of Heidelberg

Kelts LJ (1979) Ecology of a tidal marsh corixid, Trichocorixa verticalis (Insecta, Hemiptera). Hydrobiologia 64:37-57

Konar B, Iken K (2009) Influence of taxonomic resolution and morphological fuctional groups in multivariate analyses of macroalgal assemblages. Phycologia 48: $24-31$

Kratzer EB, Batzer DP (2007) Spatial and temporal variation in aquatic macroinvertebrates in the Okefenokee swamp, Georgia, USA. Wetlands 27:127-140

Leigh C, Sheldon F (2009) Hydrological connectivity drives patterns of macroinvertebrate biodiversity in floodplain rivers of the Australian wet/dry tropics. Freshw Biol 54: 549-571

Lodge DA (1985) Macrophyte-gastropod associations: observations and experiments on macrophyte choice by gastropods. Freshw Biol 15:695-708

Merritt RW, Cummins KW (2008) An introduction to the aquatic insects of North America, 4th edn. Kendall/Hunt, Dubuque, IA

> Meutter FVD, Trekels H, Green AJ, Stoks R (2010) Is salinity tolerance the key to success for the invasive water bug Trichocorixa verticalis? Hydrobiologia 649:231-238

> Mittelbach GG (1988) Competition among refuging sunfishes and effects of fish density on littoral zone invertebrates. Ecology 69:614-623

Morton T (1973) The ecological effects of water control structures on an estuarine area, White Lake, Louisiana, 1972-1973. University of Southwestern Louisiana at Lafayette, LA

Newcomb TJ, Hanna KM, Anderson MR (2001) Macroinvertebrate forage in the Smith River tailwater. Proc Annu Conf Southeast Assoc Fish and Wildl Agencies 55: 116-125

Nicolet P, Biggs J, Fox G, Hodson MJ, Reynolds C, Whitfield M, Williams $P$ (2004) The wetland plant and macroinvertebrate assemblages to temporary ponds in England and Wales. Biol Conserv 120:261-278

Nilsson AN (1986) Life cycles and habitats of the northern European Agabini (Coleoptera, Dytiscidae). Entomologica Basiliensia 11:391-417 
Olsgard F, Brattegard T, Holthe T (2003) Polychaetes as surrogates for marine biodiversity: low taxonomic resolution and indicator groups. Biodivers Conserv 12:1033-1049

Paillex A, Castella E, Carron G (2007) Aquatic macroinvertebrate response along a gradient of lateral connectivity in river floodplain channels. J N Am Benthol Soc 26: 779-796

Piazza BP, La Peyre MK (2011) Nekton community response to a large-scale Mississippi River discharge: examining spatial and temporal response to river management. Estuar Coast Shelf Sci 91:379-387

Poff NL (1997) Landscape filters and species traits: towards mechanistic understanding and prediction in stream ecology. J N Am Benthol Soc 16:391-409

Rawer-Jost C, Bohmer J, Blank J, Rahmann H (2000) Macroinvertebrate functional feeding group methods in ecological assessment. Hydrobiologia 422-423:225-232

Roach KA, Thorp JH, Delong MD (2009) Influence of lateral gradients of hydrologic connectivity on trophic positions of fishes in the upper Mississippi river. Freshw Biol 54: $607-620$

Rozas LP, Minello TJ (1999) Effects of structural marsh management on fishery species and other nekton before and during a spring drawdown. Wetlands Ecol Manag 7: 121-139

Rozas LP, Minello TJ (2010) Nekton density patterns in tidal ponds and adjacent wetlands related to pond size and salinity. Estuar Coast 33:652-666

Smith DG (2001) Pennak's freshwater invertebrates of the United States, 4th edn. John Wiley \& Sons, New York, NY

Stonedahl GM, Lattin JD (1986) The Corixidae of Oregon and Washington (Hemiptera: Heteroptera). Technical Bulletin 150, Agricultural Experiment Station, Oregon State University, Corvallis, OR

Tarr TL, Baber MJ, Babbitt KJ (2005) Macroinvertebrate community structure across a wetland hydroperiod gradient in southern New Hampshire, USA. Wetlands Ecol Manag 13:321-334

ter Braak CJF, Smilauer P (2002) CANOCO Reference manual and CanoDraw for Windows user's guide: software for canonical community ordination (version 4.5), Microcomputer Power, Ithaca, NY

Tockner K, Pennetzdorfer D, Reiner N, Schiemer F, Ward JV (1999) Hydrological connectivity and the exchange of organic matter and nutrients in a dynamic river-floodplain system (Danube, Austria). Freshw Biol 41:521-535

Editorial responsibility: Christine Paetzold, Oldendorf/Luhe, Germany
Tones PI, Hammer UT (1975) Osmoregulation in Trichocorixa verticalis interiors Sailer (Hemiptera, Corixidae) - an inhabitant of Saskatchewan saline lakes, Canada. Can J Zool 53:1207-1212

Velasco J, Millan A, Hernandez J, Gutierrez C, Abellan P, Sanchez D, Ruiz M (2006) Response of biotic communities to salinity changes in a Mediterranean hypersaline stream. Saline Syst 2:12

Visser JM, Sasser CE, Chabreck RH, Linscombe RG (1998) Marsh vegetation types of the Mississippi river deltaic plain. Estuaries 21:818-828

Wallace JB, Webster JR (1996) The role of macroinvertebrates in stream ecosystem function. Annu Rev Entomol 41:115-139

> Ward JV (1998) Riverine landscapes: biodiversity patterns, disturbance regimes, and aquatic conservation. Biol Conserv 83:269-278

Ward JV, Tockner K, Arscott DB, Claret C (2002) Riverine landscape diversity. Freshw Biol 47:517-539

> Whiles MR, Goldowitz BS (2005) Macroinvertebrate communities in central Platte River wetlands: patterns across a hydrologic gradient. Wetlands 25:462-472

Wicker KM, Davis D, Roberts D (1983) Rockefeller State Wildlife Refuge and Game Preserve: evaluation of wetland management techniques. Coastal Management Section, Louisiana Department of Natural Resources, Baton Rouge, LA

> Williams DD, Williams NE (1998) Aquatic insects in an estuarine environment: densities, distribution and salinity tolerance. Freshw Biol 39:411-421

- Wissinger SA (1988) Spatial distribution, life history, and estimates of survivorship in a fourteen-species assemblage of larval dragonflies (Odonata: Anisoptera). Freshw Biol 20:329-340

Wissinger SA, Greig HS, McIntosh AR (2009) Absence of species replacements between permanent and temporary lentic communities in New Zealand. J N Am Benthol Soc 28:12-23

Zilli FL, Marchese MR (2011) Patterns in macroinvertebrate assemblages at different spatial scales. Implications of hydrological connectivity in a large floodplain river. Hydrobiologia 663:245-257

Zimmer KD, Hanson MA, Butler MG, Duffy WG (2001) Size distribution of aquatic invertebrates in two prairie wetlands, with and without fish, with implications for community production. Freshw Biol 46:1373-1386

Submitted: March 14, 2012; Accepted: February 4, 2013 Proofs received from author(s): March 22, 2013 